\title{
Study of relationship between personal, situational, psychological and socio-economical characteristics with adoption of goat farming technology by the goat keepers
}

\author{
R. T. KOLI AND S. R. KOLI
}

\begin{abstract}
The study revealed that majority of the goat keepers were from middle age group, most of them were illiterate having medium size of family, majority of them were landless having medium level of herd size and majority of them were having medium annual income, low level of social participation, medium use of information sources medium level of knowledge, medium level of scientific orientation and high level of economic motivation regarding improved management practices. It was observed that the characteristics namely, age, education, family size, annual income, social participation, source of information, knowledge, scientific orientation, economic motivation and proximity to urban area had positive and significant relationship with adoption level. However, the relationship between land holding and herd size with adoption level were found non-significantly related.
\end{abstract}

KEY WORDS : Personal, Situational, Socio-economic, Characteristics, Adoption, Goat farming technology, Goat keepers

HOW TO CITE THIS PAPER : Koli, R.T. and Koli, S.R. (2016). Study of relationship between personal, situational, psychological and socioeconomical characteristics with adoption of goat farming technology by the goat keepers. Res. J. Animal Hus. \& Dairy Sci., 7(1) : 11-15 : DOI: 10.15740/HAS/RJAHDS/7.1/11-15. 